\title{
Mechanical properties of concrete frame joints with high-strength stirrups under axial and cyclic lateral loads
}

\section{Propiedades mecánicas de las juntas de armazón de hormigón con estribos de alta resistencia bajo cargas laterales axiales y cíclicas}

Julin Wang (Main and Corresponding Author)

Institute of Building Structures, Shanxi Architectural College

50 XueFu Street, Taiyuan 030006 (China)

wangjl_tj@163.com

Manuscript Code: 1307

Date of Acceptance/Reception: 07.08.2019/23.01.2019

DOI: 10.7764/RDLC.18.2.334

\begin{abstract}
In this paper, four concrete frame joints with high-strength stirrups and one with normal-strength stirrups were tested to investigate the mechanical properties of concrete beam-column joints with high-strength stirrups under low cyclic reversed loading. The influences of yield strength, volumetric ratio and section type of stirrups on bearing capacity, ductility, energy dissipation and shear deformation of concrete joints were analyzed, and the results indicate that increasing the yield strength of stirrups has limited effect on enhancing the bearing capacity of concrete joints, but can effectively improve the ductility, energy dissipation and restriction on shear deformation of concrete joints.
\end{abstract}

Key words: concrete joints; high-strength stirrups; mechanical properties

Resumen

Con el objetivo de investigar las propiedades mecánicas de las juntas de viga-hormigón con estribos de alta resistencia, se probaron cuatro juntas de marco de hormigón con estribos de alta resistencia y una con estribos de resistencia normal bajo carga invertida cíclica baja en el papel. Se analizan las influencias del límite de elasticidad del estribo, la relación volumétrica del estribo y la forma del estribo en la capacidad de carga, ductilidad, disipación de energía y deformación cortante de juntas de concreto, y los resultados indican que aumentar la resistencia al límite del estribo tiene un efecto limitado en mejorar la capacidad de soporte del concreto articulaciones, pero puede mejorar efectivamente la ductilidad, la disipación de energía y la restricción en la deformación por cizallamiento de las juntas de concreto.

Palabras clave: juntas de hormigón; estribos de alta resistencia; propiedades mecánicas.

Introduction

Brittle shear failure of joints is one of the main reasons why reinforced concrete frames are destroyed and collapse in severe earthquakes. The shear transfer mechanism in reinforced concrete frame joints and the effect of the axial compression ratio on the seismic behavior of joints were investigated (Fu, Zhang, \& Chen, 2006). This study showed that seismic performances of joints can be improved with rational allocation of stirrups, which are considered useful against shear and provide some confinement to concrete. Reversed cyclic loading tests on 6 high-strength concrete columns and 3 normal strength concrete columns (for comparison) were conducted to evaluate the seismic behaviors of high-strength concrete columns with high strength stirrups (Sun, Si, \& Wang, 2010). The test results indicated high-strength stirrups decreased the axial load ratio of the columns, which was beneficial for the ductility of concrete columns. Eight large-scale high-strength concrete square columns were built and tested under simulated earthquake 
loading (Patrick, Frederic, \& Daniel, 2001). In this test, the columns were subjected to constant axial loads corresponding to 40 and $52 \%$ of the columns' axial load capacity and to a cyclic horizontal load-inducing reversed bending moment. Based on the experimental results, Patrick $P$ et al. (2001) presented that high-yield-strength reinforcement can effectively confine high-strength concrete while reducing the volumetric ratio of lateral transverse reinforcement in some cases. Based on a series of experimental results of concrete specimens confined with high-strength lateral ties subjected to axial loading, a modified confined concrete model was developed (Shi, Wang, \& Wang, 2013). The study on thirty-two simply supported reinforced concrete (RC) beams with high-strength stirrups presented the effects of the yield strength of shear reinforcement and the compressive strength of concrete on the shear behavior of RC beams (Jung-Yoon, Im-Jun, \& Sang-Woo, 2011). The addition of steel fiber-reinforced concrete at the critical regions can enhance the seismic performance of reduced-scale gravity-load designed test frames (Oinam, Sahoo, \& Sindhu, 2014). The experiment results showed that the addition of steel fibers improved the damage tolerance, lateral load resisting capacity, lateral stiffness, ductility and energy dissipation of the frame. There was a new-type of fabricated beam-column connections with end plates (Li, Li \& Jiang, 2017). The diagonally bent configuration of beam longitudinal bars in the beam-column joints resulted in the shear failure at the joint region against the flexural of beams having straight bar configurations (Oinam, Kumar, \& Sahoo, 2019), which can indicate the effectiveness of steel fiber-reinforced concrete in reducing the transverse shear stirrups in beam-column joints of the reinforced concrete frames with strong-columns and weak-beams.

This paper presents the results of an experimental program which was carried out to investigate the different parameters that affect the behavior of concrete frame joints with high-strength stirrups; the experimental program consists of five cruciform specimens. The main parameters are: yield strength, volumetric ratio and section type of stirrups.

Experimental Program

\section{Specimens}

Five reinforced concrete beam-column joint specimens are designed for the test investigation, where RC- 1 is a specimen with ordinary-strength stirrups and RC-2, RC-3, RC-4 and RC-5 are with high-strength stirrups. Each specimen consists of one beam with cross section $200 \mathrm{~mm} \times 350 \mathrm{~mm}$ and length $2900 \mathrm{~mm}$, and one column with cross section $300 \mathrm{~mm} \times 300 \mathrm{~mm}$ and height $1900 \mathrm{~mm}$. A clear cover of $15 \mathrm{~mm}$ thickness was provided to all specimens. There are two arrangement forms for stirrups in the test: rectangular and well-shaped. The concrete dimensions and steel reinforcement details of all specimens are shown in Figure 1 and listed in Table 1, respectively.

Table 1. Reinforcement arrangement of specimens. Source: Own preparation

\begin{tabular}{cccccccc}
\hline & \multicolumn{2}{c}{ Beams } & \multicolumn{2}{c}{ Columns } & \multicolumn{3}{c}{ Stirrups of Joints } \\
\cline { 2 - 7 } Specimen & Longitudinal & & Longitudinal & \multicolumn{2}{c}{ Diameter and } & Volumetric \\
bars & Stirrups & bars & Stirrups & Spacing $(\mathrm{mm})$ & Section type & Ratio (\%) \\
\hline RC-1 & $3 \varphi 22$ & $8 @ 60 / 90$ & $12 \varphi 18$ & $6.5 @ 80$ & $6.5 @ 100$ & Well shape & 1.06 \\
RC-2 & $3 \varphi 22$ & $7 @ 60 / 90$ & $12 \varphi 18$ & $5 @ 60$ & $5 @ 60$ & Well shape & 1.05 \\
RC-3 & $3 \varphi 22$ & $7 @ 60 / 90$ & $12 \varphi 18$ & $5 @ 60$ & $5 @ 75$ & Well shape & 0.84 \\
RC-4 & $3 \varphi 22$ & $7 @ 60 / 90$ & $8 \varphi 22$ & $7 @ 60$ & $7 @ 60$ & Rectangle & 1.03 \\
RC-5 & $3 \varphi 22$ & $7 @ 60 / 90$ & $8 \varphi 22$ & $7 @ 60$ & $7 @ 75$ & Rectangle & 0.82 \\
\hline
\end{tabular}


Figure 1. Concrete dimensions and steel reinforcement details of specimens (unit: $\mathrm{mm}$ ). Source: Own preparation.
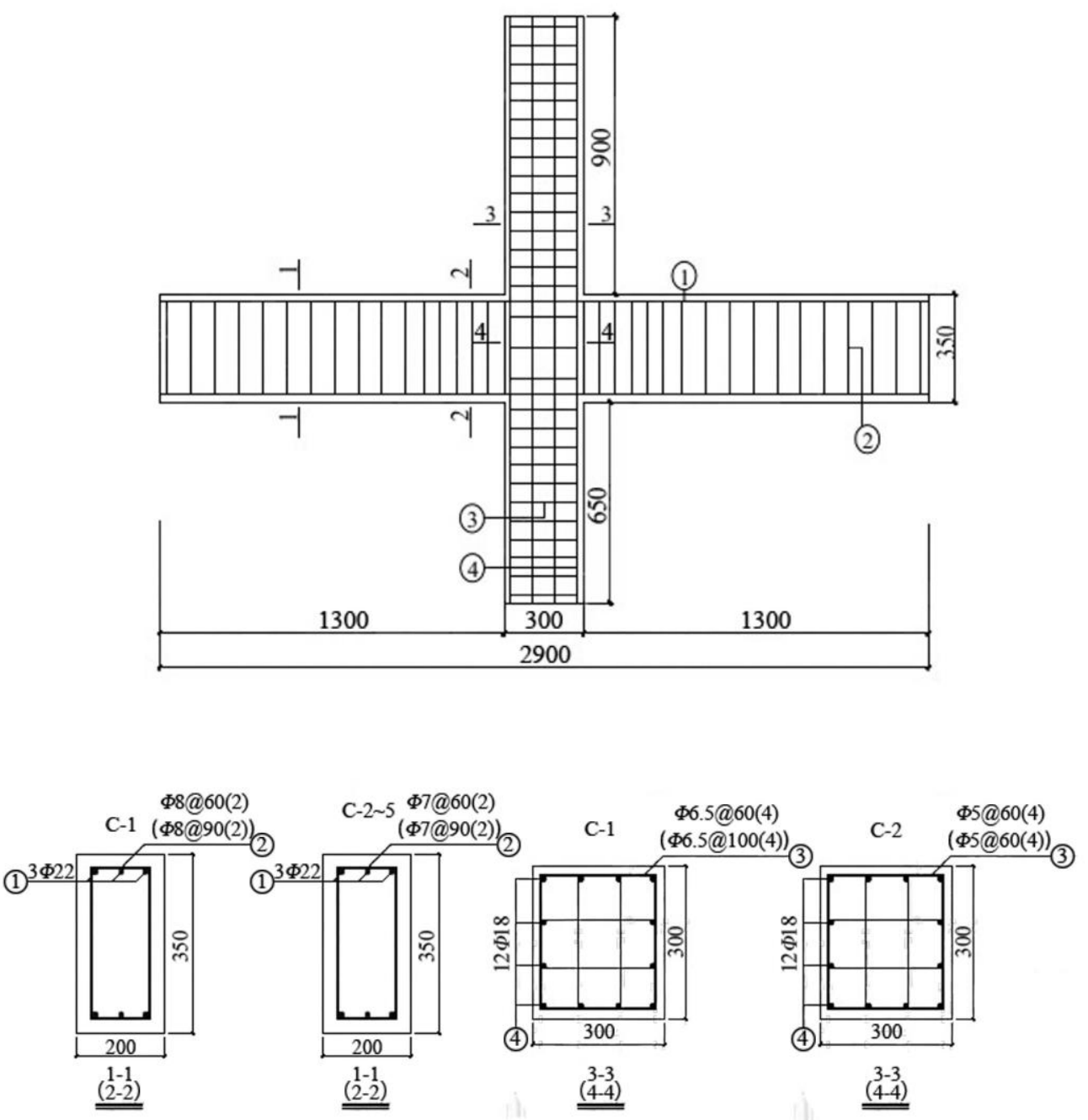

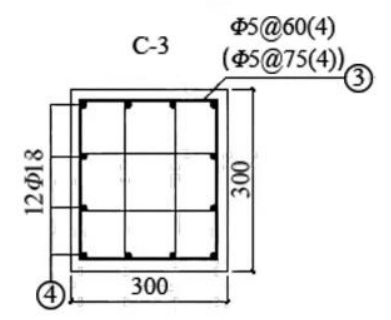

$\underline{\underline{(4-4)}}$

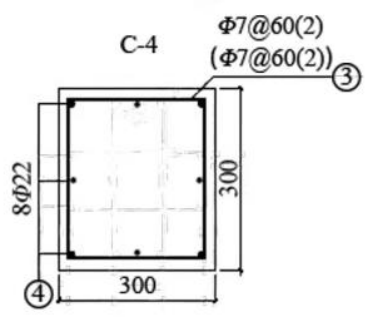

$\underline{\underline{(4-3)}}$

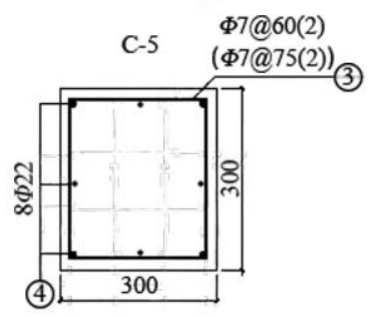

$\underline{\underline{(4-4)}}$

\section{Materials properties}

According to the standard for test method of mechanical properties on high strength concrete (China Academy of Building Research, 2012; China Academy of Building Research, 2002), material tests of concrete are performed. The test results indicate that the concrete compressive cube strengths of beams and columns are $59.27 \mathrm{MPa}$. The axial compressive strength is calculated as 47.17 MPa (Liang, Ma, \& Deng, 2008). Deformed steel bars with grade HRB400 having different diameters of $18 \mathrm{~mm}$ and $22 \mathrm{~mm}$ are used for main longitudinal reinforcement steel of the beams and columns. Normal strength stirrups are grade HPB235 smooth steel bars with $6.5 \mathrm{~mm}$ diameter and grade HRB335 deformed steel bars with $8 \mathrm{~mm}$ diameter, respectively. High strength stirrups are deformed steel bars with different diameters of 5 and $7 \mathrm{~mm}$. The stress-strain curve of high-strength stirrups is shown in Figure 2. 
Figure 2. Stress-strain curve of high-strength stirrups. Source: Own preparation.

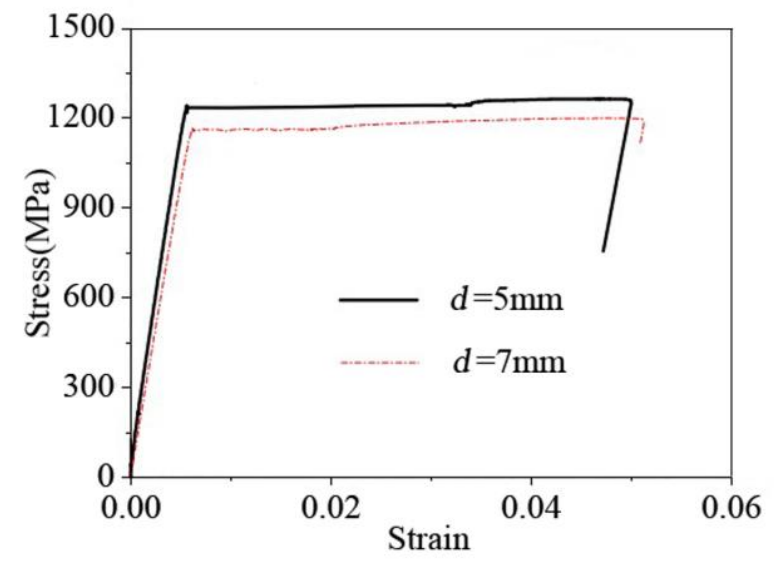

Table 2. Mechanical properties of reinforcement. Source: Own preparation.

\begin{tabular}{|c|c|c|c|c|}
\hline Species & $\begin{array}{l}\text { Diameter } \\
\text { (mm) }\end{array}$ & $\begin{array}{c}\text { Yield } \\
\text { strength } \\
\text { (MPa) }\end{array}$ & $\begin{array}{c}\text { Percentage } \\
\text { elongation (\%) }\end{array}$ & $\begin{array}{c}\text { Elastic } \\
\text { modulus } \\
(\mathrm{MPa})\end{array}$ \\
\hline HRB235 & 6.5 & 375 & 18.3 & $2.29 \times 10^{5}$ \\
\hline HRB335 & 8.0 & 409 & 26.0 & $1.69 \times 10^{5}$ \\
\hline \multirow[t]{2}{*}{ HRB400 } & 18 & 438 & 37.1 & $1.83 \times 10^{5}$ \\
\hline & 22 & 448 & 37.1 & $1.86 \times 10^{5}$ \\
\hline High-stren & 5.0 & 1238 & 10.2 & $2.19 \times 10^{5}$ \\
\hline $\begin{array}{l}\text { gth } \\
\text { stirrups }\end{array}$ & 7.0 & 1167 & 9.14 & $1.97 \times 10^{5}$ \\
\hline
\end{tabular}

\section{Experimental setup and loading system}

In this test, pseudo static cyclic loading is used. The experimental loading setup is shown in Figure 3. The test setup consists of a 100T horizontal actuator applied at the column end and a $1000 \mathrm{kN}$ capacity hydraulic jack positioned vertically at the top of column. The bottom of the column is connected to a ground beam by a fixed hinge bearing, and the beam ends are connected to ground beams by chain rods. By setting lateral supports in the middle of the beam, it is ensured that no out-of-plane deformation of specimens will occur during the loading.

At the beginning of the test, the experimental vertical load was applied to the expected constant value determined by the designed axial compression ratio. The axial compression ratio of five specimens was 0.3 , so the value of vertical load was $1246.59 \mathrm{kN}$.

The horizontal cyclic load was applied after vertical loading. Based on the Specification of Test Methods for Earthquake Resistant Building (China Architecture and Building Press, 2015), the mixed load and displacement control was adopted in the test. Before the specimens yielded, the load-control was used and repeated once at each control point, with a load increment of $10 \mathrm{kN}$. After the specimen yielded, the displacement control was used, the incremental value was 0.2 times of the yield displacement, and the load was cycled for three times. The loading was stopped when the specimen was damaged or decreased to $85 \%$ of its peak value. 


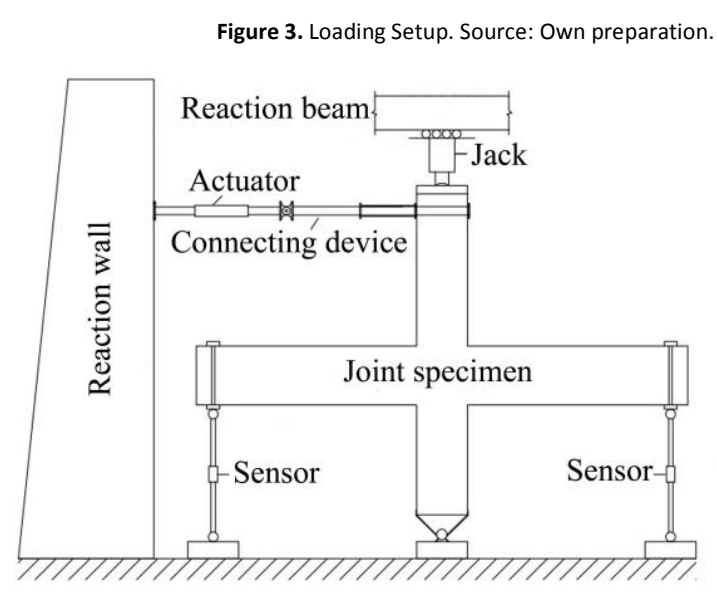

\section{Arrangement of measurement point}

The following items were observed and measured in the test: the horizontal load and displacement at the column top under each level of load, the vertical reaction force on the beam end, the shear deformation of the joints, and the steel strain. A displacement meter was placed on the column top to measure its horizontal displacement. To measure the reaction force, a force sensor was placed on each end of the beam. A cross dial indicator was placed at the joint to measure the shear deformation.

Eight strain gauges were placed on the longitudinal reinforcements of the beam, numbered BL1 BL4 and BR1 BR4 from the left to the right, respectively. Four strain gauges were placed on the longitudinal reinforcements of the column, numbered $\mathrm{C} 1^{\sim} \mathrm{C} 4$ from the top to the bottom. To investigate the strain-changing rule of stirrups, the strain gauges were placed on the stirrups of the plastic hinge area in the beam and of the joint area, numbered S1 S6 and J1 J3. The detailed layouts are shown in Figure 4.

Meanwhile, the horizontal load was measured by a tension-compression sensor. The data of displacement, dial indicator, tension-compression sensor and strain gauges placed on reinforcements were collected by static resistance strain gauges.

Figure 4. Layout of test devices. Source: Own preparation.

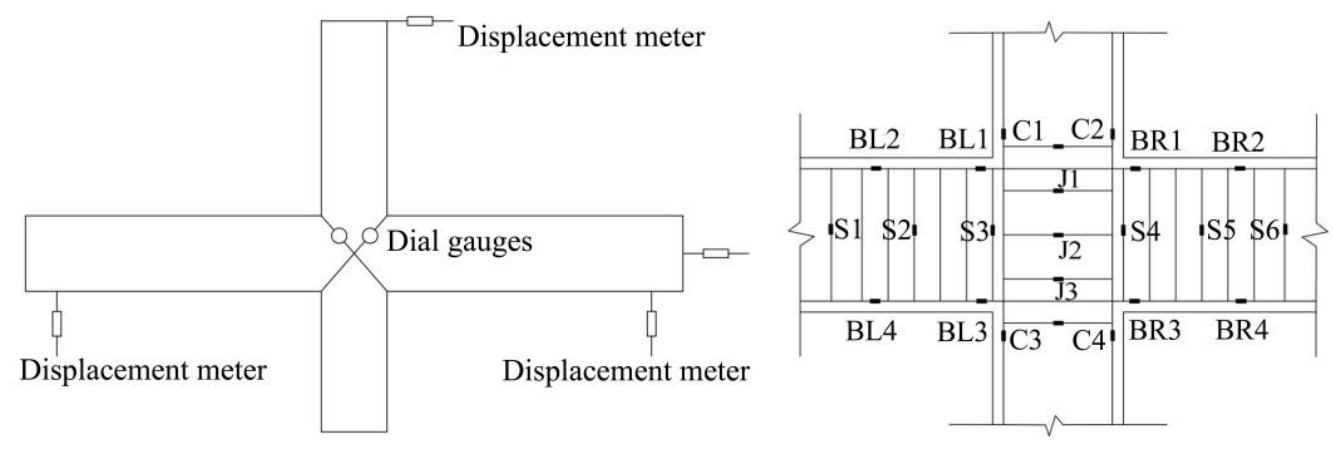

(a) Layout of displacement meters

(b) Layout of steel strain gauges

\section{Experimental phenomenon}

The failure processes of five specimens were basically similar to each other, and each specimen had experienced four stages: cracks appearing, cracks developing, reaching limit and being damaged. At the early stage of horizontal load 
cycles, the specimens were mostly in an elastic stage, and there were no cracks on the concrete surface, indicating that the relationship between load and horizontal displacement was approximately linear.

When the horizontal load reached $20 \mathrm{kN} \sim 40 \mathrm{kN}$, the first flexural crack appeared at the tension side of the beam, which was about $10 \mathrm{~cm} \sim 20 \mathrm{~cm}$ away from the edge of the joint. With the increase of horizontal load, the original crack further extended with the occurrence of new cracks on the left and right sides of the first crack. When the horizontal load was increased to $60 \mathrm{kN} \sim 80 \mathrm{kN}$, some cracks began to appear on the beam ends near the joint, and at the same time, there were hair oblique cracks on the other beam ends. When the horizontal load reached $100 \mathrm{kN} \sim 110 \mathrm{kN}$, a shear crack of about $0.1 \mathrm{~mm}$ width appeared near the intersection of the diagonals of the joint core, and some oblique cracks began to occur along the other diagonal on loading in the opposite direction. With the increase of horizontal load, the forward and reverse cracks gradually increased and extended. When the load was increased to $120 \mathrm{kN} \sim 140 \mathrm{kN}$, the cracks in the core zone of the joint gradually developed into X-shaped cross diagonal cracks, and the concrete in the core zone was divided into several irregular quadrangular small blocks. At this time, the vertical cracks of the beam were connected, the width of the oblique cracks was widened further, and horizontal cracks began to occur on the column. When the horizontal load reached $150 \mathrm{kN} 160 \mathrm{kN}$, the X-shaped cross oblique cracks became main cracks and their width increased to about $0.6 \mathrm{~mm}$.

After the specimens were yielded, the controlling displacement increment method was adopted. As the loading continued to the ultimate load (170 kN 180 kN), the main cracks continued to widen, accompanied by broken sounds of the concrete, and the small concrete blocks of the protection layer gradually separated and fell off. After the loading exceeded the peak value, the concrete cover was spalled off in a large area, and the longitudinal reinforcements underwent severe buckling. When the bearing capacity of specimens decreased to $85 \%$ of its peak load, the specimens were under failure as shown in Figure 5, and the loading was stopped.

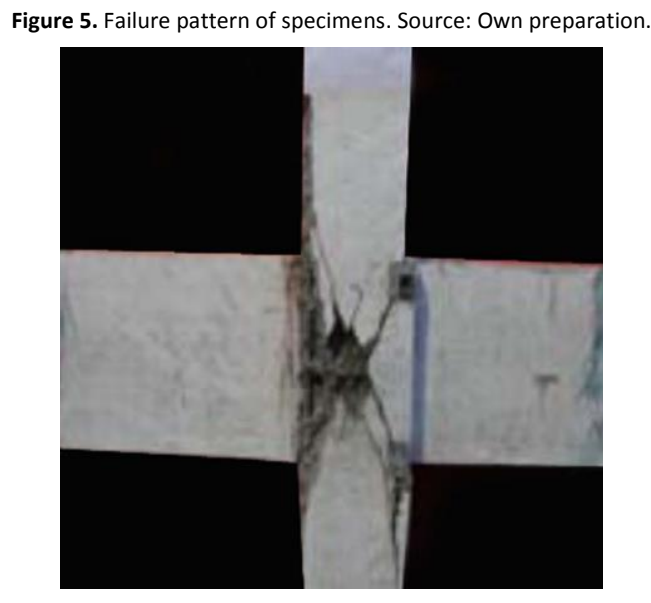

Results and discussion

\section{Hysteretic behaviors}

\section{Load-displacement hysteretic curves}

The horizontal load-displacement hysteretic curves on the top of columns for all specimens are shown in Figure 5. From these figures, it can be seen that at the early stage of horizontal load cycles, the hysteretic loops are narrow and slender, the residual deformation is small after unloading, and thus the area encircled by the hysteretic curves is small. The slopes of curves change little and so does the change of stiffness. As the loading continues, the area encircled by hysteretic curves increases and so does the residual deformation of the specimens after unloading. 
Meanwhile, the stiffness of the specimens gradually decreases, and the hysteresis curves begin to pinch. After the yield of the specimens, the hysteresis loop is inverted S-shaped, and there are significant degradations of both strength and stiffness, together with the bond-slip phenomena. After the load reaches its peak value, the curves decrease slowly and the load-carrying capacity of the specimens begins to decrease, the energy consumption continues to increase, and the pinching phenomenon becomes more conspicuous. The bearing capacity of the all specimens decreases steadily until they fail, which shows great ductility.

By comparing the hysteresis curves of the specimens in Figure 6, it can be seen that the stirrup strength and the stirrup ratio are important factors affecting the hysteretic behaviors of the specimens. When the volumetric percentages of stirrups are the same, the deformation capacity of the specimen with high-strength stirrup (RC-2) is better than that of the ones with ordinary stirrup (RC-1) and the lower stirrup ratio (RC-3), and the force-displacement hysteresis curves of the former are fuller, exhibiting that high-strength stirrups can enhance both the energy dissipation capacity and ductility of concrete joints to some extent.

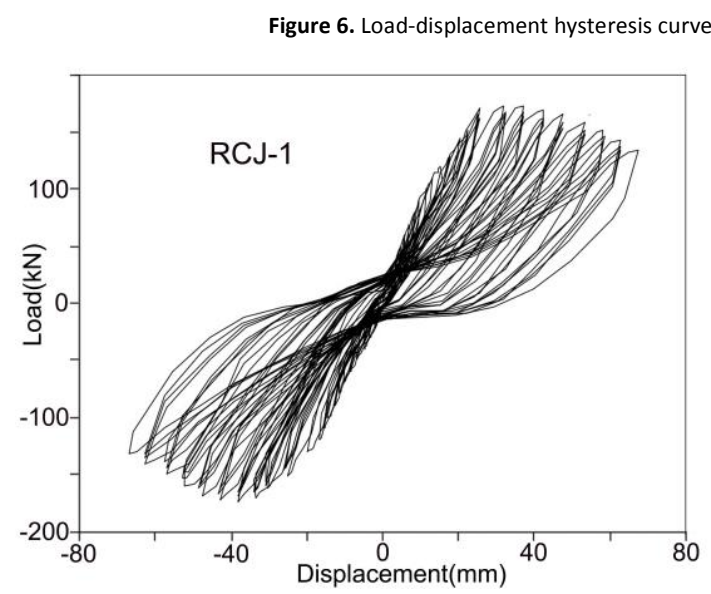

(a) RC-1

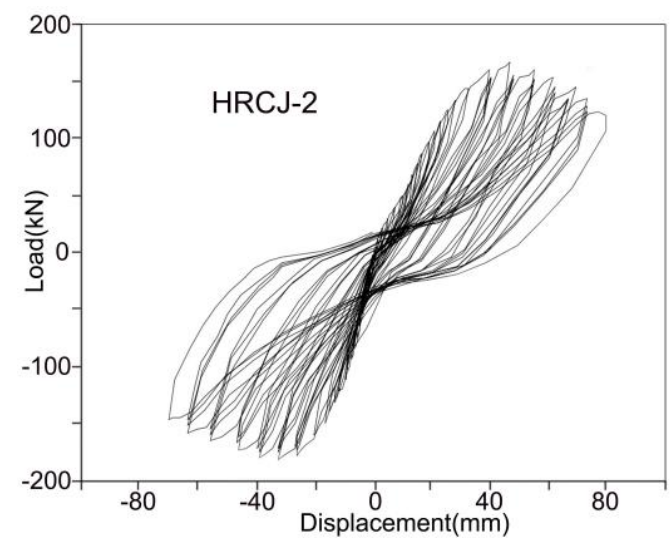

(c) RC-3

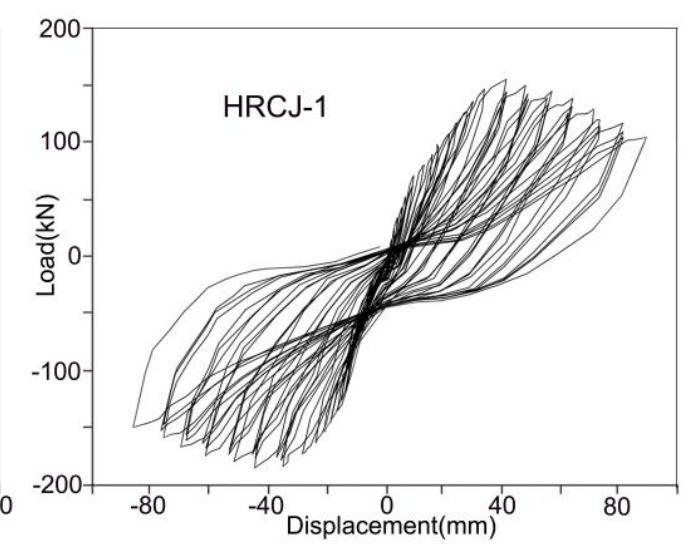

(b) RC-2

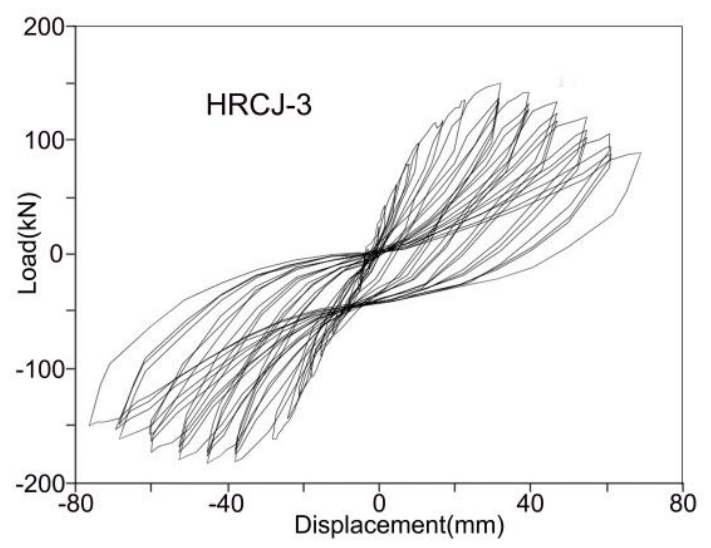

(d) RC-4 


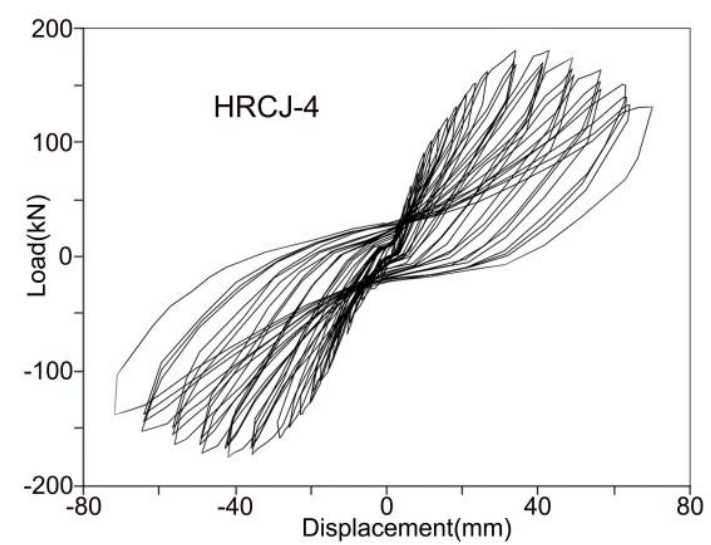

(e) RC-5

\section{Shear stress-shear angle hysteresis curve}

When the shear force at the joint core reaches its maximum value, the bending moment of the beam end is lower than its yield bending moment calculated from the measured material strength (China Academy of Building Research, 2012). Therefore, it can be considered that the shear failure of the joints occurs before the plastic hinge of the beam appears, which indicates the failure of the joints is mainly caused by the combined effect of the beam and column shear forces. The horizontal shear and shear angles of the joints are calculated according to equations (1) and (2) (Yu Q., \& Li S. M., 2006), respectively, as shown in Figure 7. The shear stress-shear angle hysteresis curves of the joints are shown in Figure 8, from which we can see that these curves are inverted S-shaped and it has obvious pinching phenomenon. When the joint area begins to crack, the shear deformation gradually increases. At the late stage of loading, the shear deformation of the specimens with high-strength stirrups (RC-2) is generally smaller than that of the ones with the normal stirrups (RC-1), showing that the high-strength stirrups can better confine concrete and greatly improve the shear bearing capacity of the concrete joints.

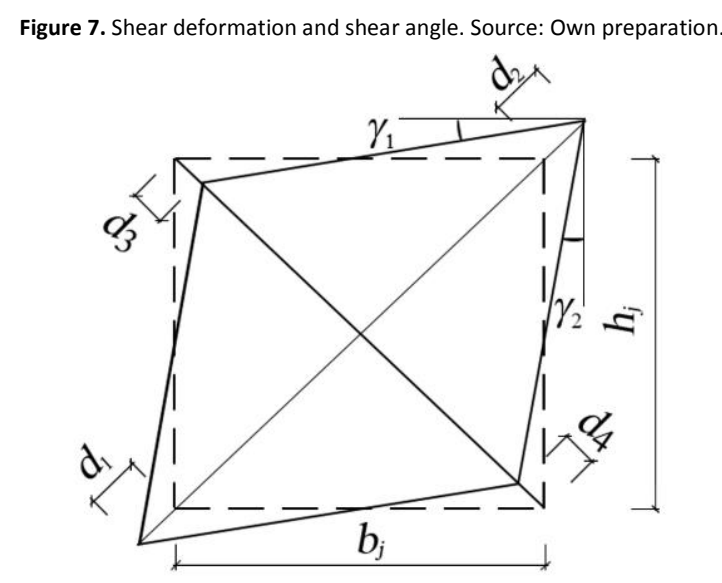

$V_{j h}=\frac{M_{b}^{L}+M_{b}^{r}}{h_{b 0}-a_{s}^{r}}-V_{c}$

Where, $V_{j h}$ and $V_{c}$ are the nodal shear and loads on the column top, respectively; $M_{b}^{l}$ and $M_{b}^{r}$ are the bending moments of the left and right ends of the beam, which are the product of the reaction force of the sensors and the length of the beam $(1.2 \mathrm{~m}) ; h_{b 0}$ is the effective height of the beam; $a_{s}^{r}$ is the distance from the longitudinal reinforcement of the compression zone to the compression edge of the section. 
$\gamma=\gamma_{1} \gamma_{2}=\frac{\sqrt{h_{j}^{2}+b_{j}^{2}}}{h_{j} b_{j}} \frac{d_{1}+d_{2}+d_{3}+d_{4}}{2}$

Where, $d_{1}, d_{2}, d_{3}$ and $d_{4}$ are the deformations of the diagonals of the joints, respectively; $h_{j}$ and $b_{j}$ are the height and width of joints, respectively; $\gamma_{1}$ and $\gamma_{2}$ are the shear angles of the joints.

Figure 8. Shear stress-shear angle hysteresis curve of joints. Source: Own preparation.

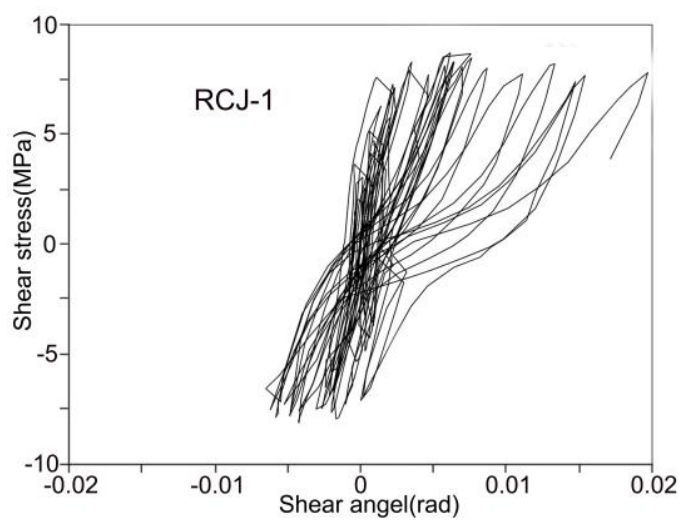

(a) RC-1

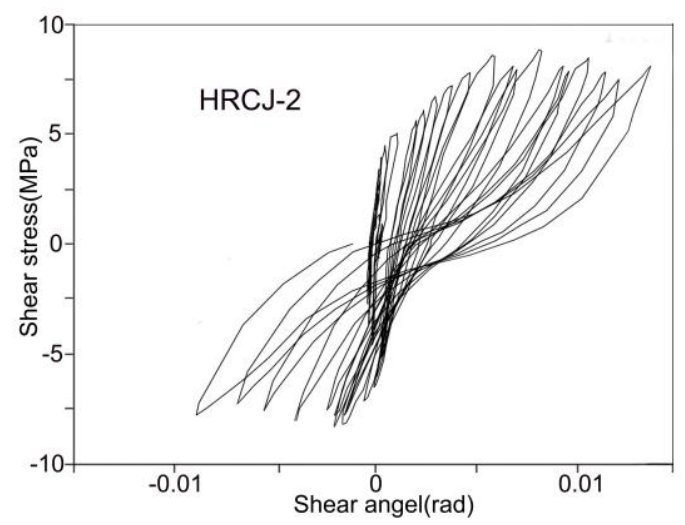

(c) RC-3

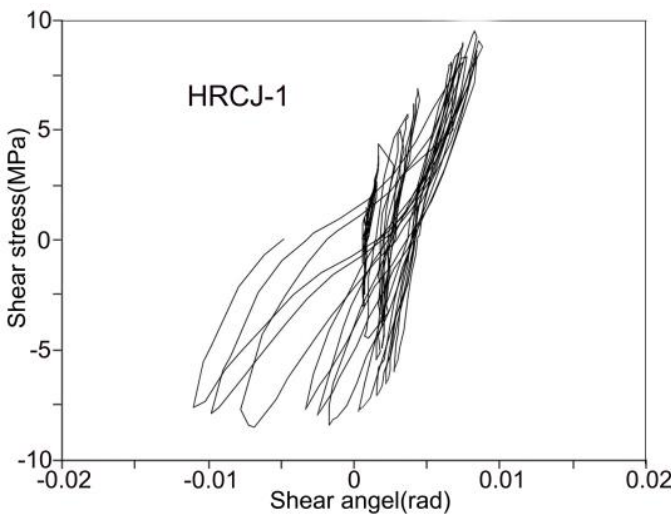

(b) RC-2

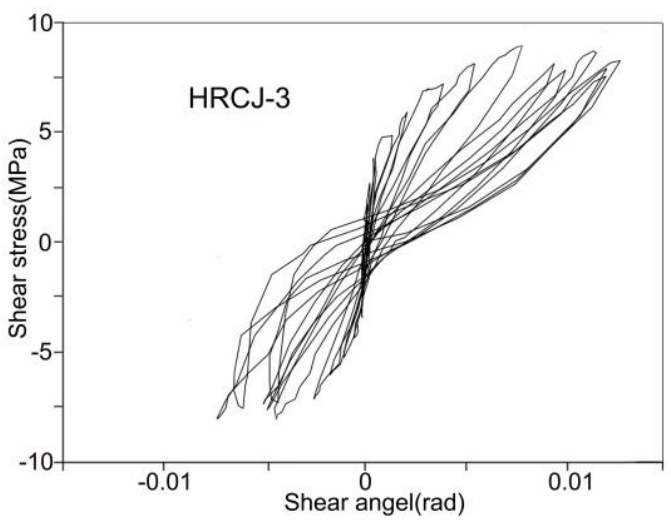

(d) RC-4

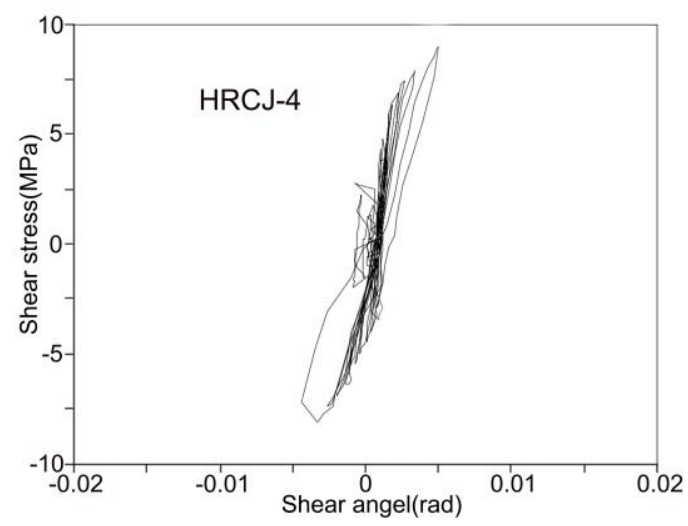

(e) RC-5

\section{Skeleton curves}

The skeleton curves derived from the hysteresis curves are a valuable tool for quantifying seismic performance index. Figure 9 shows the backbone curves of all test specimens. As can be seen from Figure 9 , in the initial stage of loading, 
the stiffness of each specimen is basically the same. Then, it is mainly analyzed for the influence of stirrup parameters on the bearing capacity and deformation.

\section{1) Strength of stirrups}

It can be seen from Figure 9 that for the specimens with the same volumetric stirrup ratio and stirrup forms, increasing yield strength of stirrups does not significantly improve the bearing capacity and maximum shear stress of the specimens. The ratio of the shear angles of the specimen RC- 2 and RC-1 is 0.61 , which indicates that the high-strength stirrups have better ability of limit to shear deformation in joints than ordinary- strength stirrups.

\section{2) Volumetric stirrup ratio}

With the increase of volumetric stirrup ratio, the bearing capacity and the maximum shear stress of the specimens do not change significantly, but the deformation performance of the specimens with high-strength stirrups constraints is improved. As shown in Figure 9, the ratio of the bearing capacity and the maximum shear stress of between HRCJ-1 and HRCJ-2 are 0.99 and 1.02, respectively, and the limit displacement of HRCJ-1 is 1.14 times higher than that of HRCJ-2.

\section{3) Stirrup forms}

As can be seen from Figure 9, the limit displacement of HRCJ-1 is 1.18 times higher than that of HRCJ-3, and the ratio of the bearing capacity $\mathrm{HRCJ}-1$ and $\mathrm{HRCJ}-3$ is 1.01 . When the strength of stirrups is close and the volumetric stirrup ratio is the same, the bearing capacity and the maximum shear stress of the specimens with composite stirrups have a little difference from the ones with rectangular stirrups, but the deformation performance of the former is better than the latter, indicating composite stirrups can reduce the shear deformation of joints.
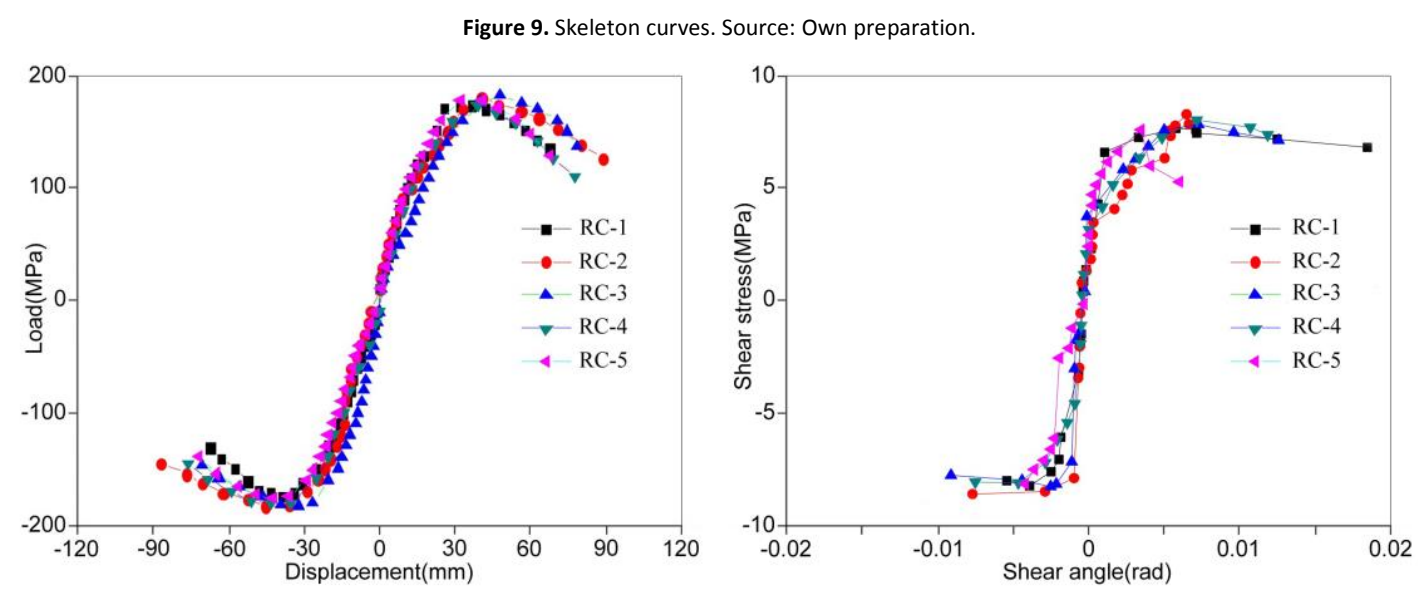

\section{Ductility analysis}

Ductility capacity is an important parameter for evaluating structure seismic capacity. In this paper, the ductility coefficient $\mu$ is defined as the ratio of limit displacement $\Delta_{u}$ to yielding displacement $\Delta_{y}$. The limit displacement is the corresponding displacement value when the bearing capacity drops to $85 \%$ of the peak value, and the yield displacement is determined according to the equivalent energy method (Park R., 1989). The ductility coefficients of the specimens are shown in Table 3. Positive numbers and negative numbers in the table indicate eigenvalues in push 
and pull direction, respectively. The left values in the ductility column represent the ductility coefficient in push and pull direction, and the right shows the mean values, which are calculated by equation (3):

$\mu=\left(\Delta_{u}^{+}+\Delta_{u}^{-}\right) /\left(\Delta_{y}^{+}+\Delta_{y}^{-}\right)$

It can be seen from Table 3, the ductility coefficient of the specimens ranges from 2.33 to 2.65 , the specimen RC-5 has the lowest ductility, and RC-2 exhibits good deformation under the constraint of high strength compound stirrup, whose ductility coefficient is $9 \%$ higher than RC-1, which demonstrates that the high strength compound stirrup has a satisfactory effect on concrete.

\begin{tabular}{ccccccc}
\multicolumn{7}{c}{ Table 3. Load characteristic values and displacement ductility. Source: Own preparation. } \\
\hline \multirow{7}{*}{$\begin{array}{c}\text { Specimen } \\
\text { number }\end{array}$} & Yield load & displacement & Limit load Limit displacement & & \\
\hline RC-1 & $(\mathrm{kN})$ & $(\mathrm{mm})$ & $(\mathrm{kN})$ & $(\mathrm{mm})$ & Ductility factor \\
\hline & 148.1 & 22.00 & 147.6 & 60.55 & 2.75 & 2.43 \\
& -155.0 & -26.94 & -148.0 & -58.17 & 2.16 & \\
RC-2 & 148.0 & 26.74 & 153.0 & 70.49 & 2.64 & 2.65 \\
& -169.0 & -28.44 & -155.8 & -75.81 & 2.39 & \\
RC-3 & 162.9 & 34.54 & 155.6 & 72.59 & 2.10 & 2.59 \\
& -155.7 & -18.82 & -155.4 & -65.68 & 3.49 & \\
RC-4 & 149.5 & 25.79 & 148.0 & 54.46 & 2.31 & 2.37 \\
& -163.3 & -27.35 & -154.0 & -71.22 & 2.60 & \\
RC-5 & 152.1 & 22.44 & 151.9 & 58.55 & 2.61 & 2.33 \\
& -164.4 & -31.31 & -150.3 & -66.80 & 2.13 & \\
\hline
\end{tabular}

\section{Energy dissipation}

When structures enter the elastic-plastic stage, its energy-dissipating capacity determines the seismic performance to a great extent, and it is reflected by the area surrounded by load-displacement curve that how much energy can be absorbed in the test. In this paper, the component's energy dissipation is evaluated by equivalent viscous coefficient $h_{e}$, which is calculated as follows:

$h_{e}=\frac{1}{2 \pi} \frac{S_{A B C D}}{S_{O B E}+S_{O D F}}$

Where, $S_{A B C D}$ represents the area enclosed by a cyclic hysteresis curve; SOBE and SODF represent the areas within the triangle $O B E$ and $O D F$, respectively, as shown in Figure 10. 
Figure 10. Hysteresis loop energy. Source: Own preparation.

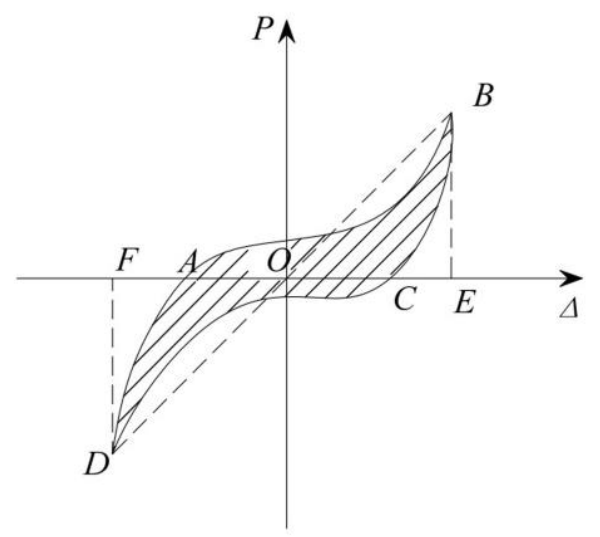

Figure 11. Comparison of average values of $h_{e}$. Source: Own preparation.

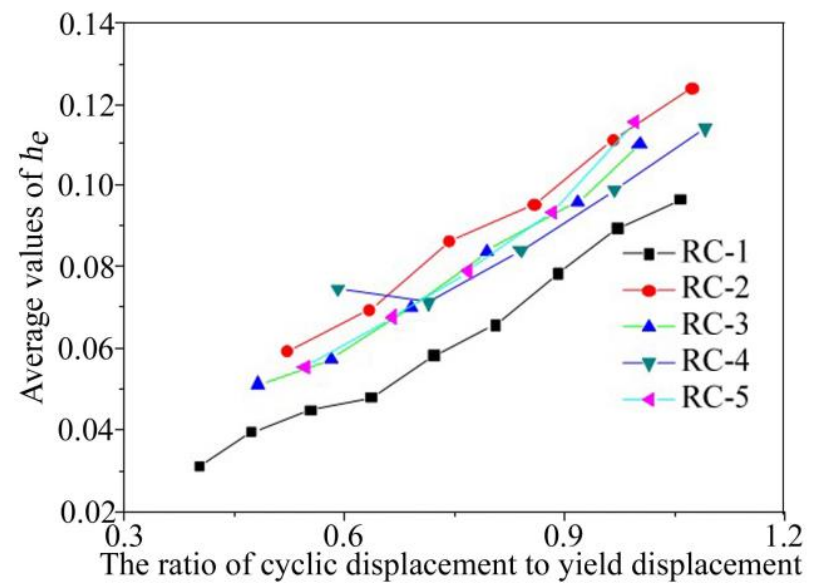

Figure 11 shows the equivalent viscous damping coefficient of all specimens. It can be seen from the figure that the equivalent viscous damping coefficient of the specimens with high-strength stirrups reaches 0.1 or more at the peak load, while that of the ordinary-stirrup specimen is less than 0.1 , showing that the energy consumption capacity of the specimens with high-strength stirrups is superior to the ordinary-stirrup specimen. The equivalent viscous damping coefficient of RC-2, RC-3 and RC-4 is $26 \%, 20 \%$ and $12.2 \%$ higher than RC-1, respectively, which indicates that the specimens with high-strength composite stirrups have the best energy dissipation capabilities, and reducing stirrup ratio or using rectangular stirrups lowers energy dissipation capacity of high-strength stirrups.

\section{Stirrup stress}

The measured stirrup strain in the joint core at different stages can be seen from Figure 12, where the two vertical lines represent the peak displacement and the limit displacement, respectively, and the horizontal line represents the yield strain of the stirrups. The stirrups of RC-1 yield at the peak load, indicating the restraint and shear resistance of common stirrups to the joints are fully used. For the specimens with high-strength stirrups, the high-strength stirrups do not yield under the peak load. The average stress of the stirrups of RC- 2 and RC-5 is about $55 \%$ and $45 \%$ the yield strength, respectively, showing that composite stirrups with high ratio have a better restraining effect on concrete joints. 


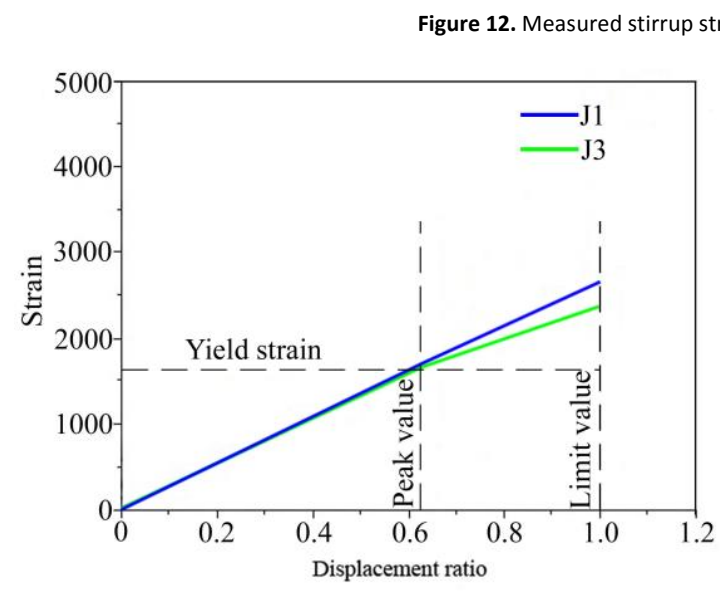

(a) RC-1

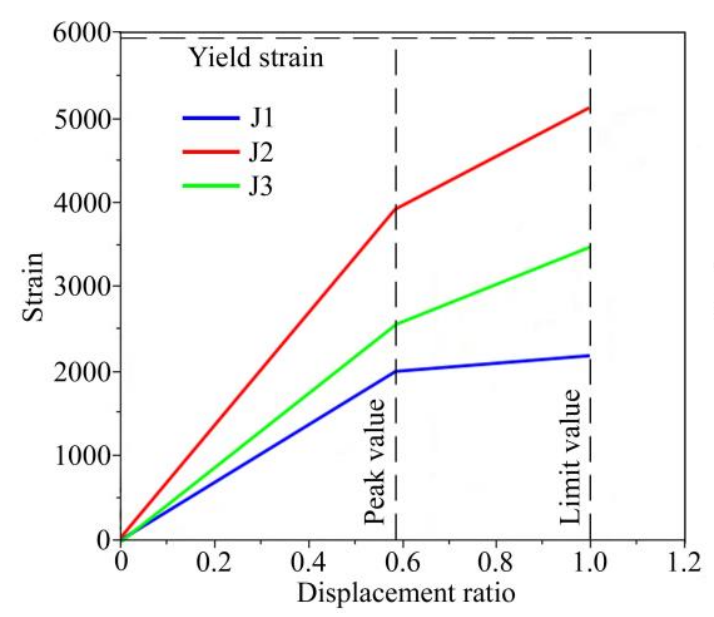

(c) RC-3

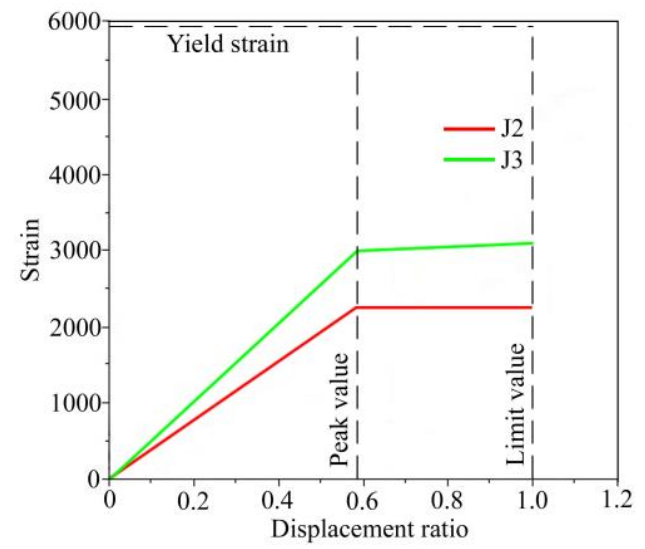

(b) RC-2

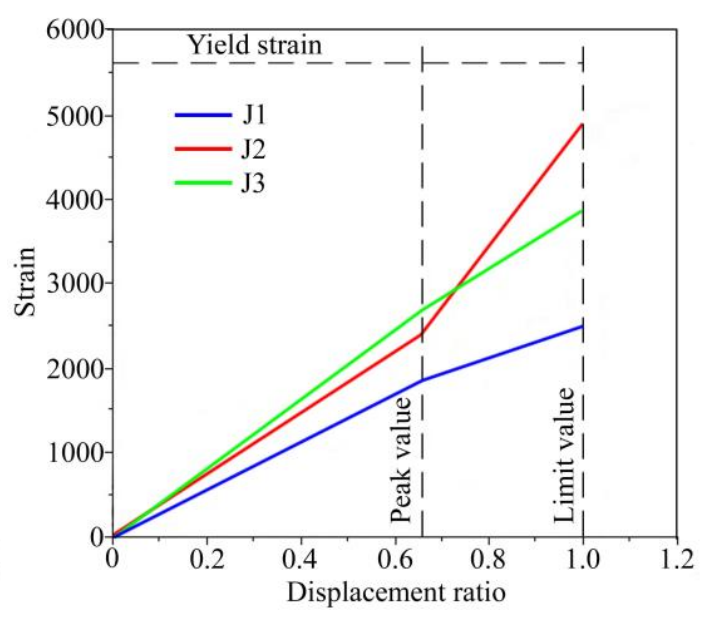

(d) RC-4

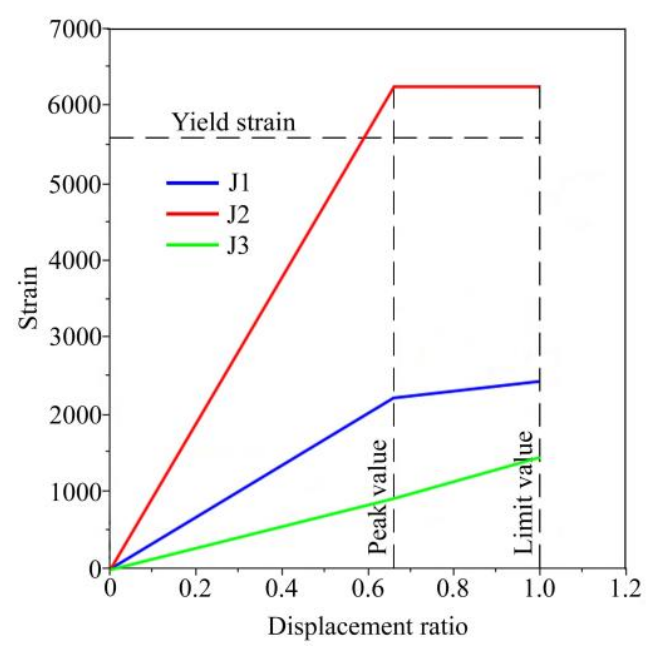

(e) RC-5

- In the experimental process, the mechanical properties of concrete joints with high-strength stirrup presented well, indicating that high-strength stirrups can work well together with concrete, which can be applied in practical engineering. 
- High-strength stirrups can enhance the deformability and ductility of the joints and effectively limit the shear deformation in joint core. Moreover, high-strength stirrups improve the ductility of concrete joints more effectively than high-strength rectangular stirrups.

- High-strength stirrups have higher total energy consumption and exhibit better energy dissipation capacity.

- It is recommended to use high-strength stirrups in joints of reinforced concrete frame structures, especially under earthquake loads.

\section{Acknowledgements}

The author would like to acknowledge the support of Dr. Tang Shougao, Tongji University, China, and Professor Zhang Zeping, Head Department of Civil Engineering, Taiyuan University of Technology, China, for their invaluable support and encouragement.

China Academy of Building Research (2002). GB/T 50082-2009. Standard for test methods of long-term performance and durability of ordinary concrete. China Architecture \& Building Press, Beijing. [in Chinese].

China Academy of Building Research (2012). JGJ/T 281. Technical specification for application of high strength concrete. China Architecture \& Building Press, Beijing. [in Chinese].

China Architecture and Building Press (2015), JGJ/T 101. Specification for Seismic Test of Buildings. Beijing, China: China Architecture and Building Press. [in Chinese].

Fu J. P., Zhang C., \& Chen T. (2006). Experimental investigation of shear mechanism and effect of axial compression ratio on joints in earthquake resistant reinforced concrete frames. Journal of Building Structures, 27(3), 67-77.

Jung-Yoon, L., Im-Jun C., \& Sang-Woo K. (2011). Shear behavior of reinforced concrete beams with high strength stirrups. American Concrete Institute, ACI Structural Journal, 108(5), 620-629.

Liang X. W., Ma L. W., \& Deng M. K. (2008). Several problems in the instruction of concrete structure course. Building Structure, 38, $72-74$.

Li S. F., Li Q. N., \& Jiang H. T. (2017). Experimental Research on Seismic Performance of a New-Type of R/C Beam-Column Joints with End Plates. Shock and Vibration, 5, 1-11.

Oinam, R. M., Kumar, P. C. A, \& Sahoo, D. R. (2019). Cyclic performance of steel fiber-reinforced concrete exterior beam-column joints. Earthquakes and Structures, $16(5), 533-546$.

Oinam, R. M., Sahoo, D. R., \& Sindhu, R. (2014). Cyclic Response of Non-ductile RC Frame with Steel Fibers at Beam-column Joints and Plastic Hinge Regions. Journal of Earthquake Engineering, 18(6), 908-928.

Patrick, P., Frederic L., \& Daniel M. (2001). Influence of concrete strength and transverse reinforcement yield strength on behavior of high-strength concrete columns. ACI Structural Journal, 98(4), 490-501.

Park, R. (1989). Evaluation of ductility of structures and structural assemblages from laboratory testing. Bulletin of the New Zealand National Society for Earthquake Engineering, 22(3), 155-166.

Shi Q. X., Wang N., \& Wang Q. W. (2013). Uniaxial compressive stress-strain model for high-strength concrete confined with high-strength lateral ties. Engineering Mechanics, 30(5), 131-137. 
Sun Z. G., Si B. J., \& Wang D. S. (2010). Research on the seismic performance of high-strength concrete columns with high-strength stirrups. Engineering Mechanics, 27(5), 128-136.

Yu Q., \& Li S. (2006). Research on frames eccentric joint under low frequency repeated loading. Journal of Tongji University, 34(4), 448-454. 